\title{
Strategi Investasi \& Manajemen Resiko Rumah Sakit Swasta di Bali
}

by

\author{
Ni Ketut Yunita Wulan Dewi ${ }^{(1)}$ \\ Gede Sri Darma ${ }^{(2)}$
}

\author{
Finance Director, Prima Medika Hospital Bali ${ }^{(1)}$ \\ Universitas Pendidikan Nasional (2) \\ yunitawulandewi@gmail.com ${ }^{(1)}$ \\ sridarma@undiknas.ac.id ${ }^{(2)}$
}

\begin{abstract}
The purpose of this study is to understand the investment policies of financial aspects based on risk management and to know that the investment studies are appropriate. This study uses qualitative methods that explore the implementation of risk management-based investment policies at Denpasar private hospital. Data collection uses documentation techniques and indepth interviews with the board of directors and hospital finance staff. The data is then analyzed qualitatively by data reduction, data presentation, and conclusion drawing.

The results of the calculation using the NPV method obtained a positive value of Rp. 463.592.397, the IRR method obtained an interest rate of 10,62\% and the PP method shows the return on investment within 8 years so the project is said to be feasible. Regarding investment risks, hospitals have not implemented an optimal risk management process so that it has the potential to pose a risk of loss.

The application of risk management to investment policies is important even though these investments are feasible, especially related to the development of risk mitigation strategies. This study discusses the analysis of hospital investment policy from the financial aspect, so it is expected that further research add other aspects as a reference in assessing investment feasibility.
\end{abstract}

Keywords: Investment, Risk Management, Hospital, Bali 
Tujuan dari penelitian ini adalah untuk memahami kebijakan investasi dari aspek keuangan yang berbasis manajemen risiko. Penelitian ini menggunakan metode kualitatif yang mengeksplorasi implementasi kebijakan investasi berbasis manajemen risiko pada rumah sakit swasta Denpasar. Pengumpulan data menggunakan teknik dokumentasi dan wawancara mendalam dengan jajaran direksi dan staf keuangan rumah sakit. Data selanjutnya dianalisis secara kualitatif dengan reduksi data, penyajian data, dan penarikan kesimpulan.

Hasil dari perhitungan menggunakan metode NPV (Net Present Value) diperoleh nilai positif sebesar Rp. 463.592.397, metode IRR (Internal Rate of Return) diperoleh tingkat bunga sebesar 10,62\% dan metode PP (Payback Period) menunjukkan pengembalian investasi dalam waktu 8 tahun. Terkait dengan adanya risiko investasi, rumah sakit belum menerapkan proses manajemen risiko secara optimal sehingga berpotensi menimbulkan risiko kerugian.

Berdasarkan hasil analisa NPV, IRR, dan PP terhadap investasi rumah sakit dapat dikatakan proyek layak dan dapat dilanjutkan. Penerapan manajemen risiko terhadap kebijakan investasi penting dilakukan walaupun investasi tersebut layak, terutama terkait pengembangan strategi mitigasi risiko. Penelitian ini membahas analisa kebijakan investasi rumah sakit dari aspek keuangan, sehingga diharapkan penelitian selanjutnya menambahkan aspek lain sebagai acuan dalam menilai kelayakan investasi.

Kata kunci: Investasi, Manajemen Risiko, Rumah Sakit, Bali 


\section{PENDAHULUAN}

Beberapa tahun terkahir, industri pelayanan kesehatan di Indonesia mengalami perkembangan yang pesat (Hendhana dan Darma, 2017). Menurut UU No 44 Tahun 2009, rumah sakit merupakan institusi pelayanan kesehatan yang menyelenggarakan pelayanan kesehatan perorangan secara paripurna serta menyediakan pelayanan rawat inap, rawat jalan, dan gawat darurat. Rumah sakit melaksanakan upaya kesehatan dengan tujuan meningkatkan kesadaran, kemauan, dan kemampuan masyarakat untuk hidup sehat. Pemerintah ikut berperan dengan menerbitkan berbagai aturan untuk menciptakan situasi bisnis yang lebih baik. Peluang inilah yang dimanfaatkan oleh para investor untuk membuka dan mengembangkan berbagai jenis pelayanan kesehatan (Pidada dan Darma, 2018).

Rumah sakit harus mampu mengelola pembiayaan kesehatan yang diperoleh. Pembiayaan kesehatan yang baik ditandai dengan jumlah yang mencukupi, teralokasi dengan adil, dan termanfaatkan secara berhasil guna dan berdaya guna untuk menjamin terselenggaranya pembangunan kesehatan dan derajat kesehatan masyarakat yang setinggitingginya (Bastian, 2015; Setyawati dan Darma, 2018). Dalam praktiknya, penerimaan pembiayaan umumnya dapat direalisasikan dalam wujud akun investasi untuk pembangunan infrastruktur rumah sakit, pembelian alat-alat kesehatan, dan hibah riset. Investasi tersebut hendaknya selalu mempertimbangkan prinsip biaya dan manfaat agar mampu mengelola risiko yang akan muncul di kemudian hari.

Terkait rencana pengembangan investasi, pihak manajemen perlu melakukan analisa agar dapat membuat keputusan investasi dan keputusan pendanaan yang tepat. Menurut para peneliti terdahulu Andampury, Dewi, dan Marwati (2016), yang melakukan penelitian tentang analisis kebijakan investasi alat radiologi C-Arm Rumah Sakit X berbasis cost and benefit, berkesimpulan bahwa pembelian alat radiologi C-Arm belum melalui suatu studi kelayakan guna memastikan ketepatan keputusan investasi dan tidak termasuk dalam anggaran saat itu. Rumah Sakit X hanya ingin menambahkan nilai high tech walaupun alat tersebut sangat jarang digunakan. Di sisi lain, Sucitra dan Broto (2010) juga melakukan penelitian tentang analisis investasi proyek Rumah Sakit Internasional MH. Thamrin Bogor menunjukkan bahwa hasil studi kelayakan investasi proyek Rumah Sakit International MH. Thamrin Bogor layak untuk dilaksanakan. Dengan demikian kajian terhadap suatu proyek sangat dibutuhkan karena akan menjadi dasar bagi para investor dalam memilih dan mengambil keputusan. Kesalahan dalam memilih proyek akan mengakibatkan kerugian pada modal atau sumber daya yang ada.

Segala bentuk aktivitas perusahaan memerlukan proses manajemen risiko, termasuk yang terkait dengan kebijakan investasi. Penerapan manajemen risiko menjadi tantangan 
tersendiri bagi manajemen perusahaan karena cukup sulit diimplementasikan. Jajaran direksi juga harus memastikan bahwa struktur organisasi, kondisi keuangan, infrastruktur, sumber daya manusia, sistem informasi, serta sistem pengendalian yang berjalan di perusahaan telah sesuai untuk mendukung implementasi manajemen risiko. Penelitian oleh Yulianingtyas, Wigati, Suparwati (2016) tentang Analisis Pelaksanaan Manajemen Risiko di Rumah Sakit Islam Sultan Agung Semarang menunjukkan bahwa pelaksanaan proses manajemen risiko di RSISA belum berjalan optimal karena masih dalam proses pemahaman staf dan berbagai upaya hanya fokus pada pelaporan saja. Dapat dikatakan kendala yang muncul berasal dari SDM, dana, waktu, dan proses. Monitoring dan review terhadap pelaksanaan manajemen risiko masih banyak terjadi keterlambatan dan copy paste laporan serta belum adanya peninjauan dan pengkajian lebih lanjut terhadap risiko untuk pembelajaran ke depan.

\section{TINJAUAN PUSTAKA}

\section{Pengertian Investasi}

Jogiyanto (2010) menyatakan bahwa investasi dapat didefinisikan sebagai kegiatan penundaan konsumsi sekarang untuk dimasukkan ke aktiva produktif selama periode waktu tertentu. Menurut Halim (2015) dan Tandelin dalam Pertiwi (2016) investasi dapat dikatakan sebagai penempatan sejumlah dana atau sumber daya lainnya pada saat ini dengan harapan untuk memperoleh keuntungan di masa yang akan datang. Dalam arti sempit investasi merupakan penanaman sejumlah dana dengan memperhatikan jangka waktu dan munculnya risiko tertentu. Dengan kata lain investasi adalah keputusan perusahaan membeli suatu faktorfaktor produksi yang akan digunakan untuk menghasilkan barang atau jasa sehingga mampu mendatangkan manfaat dan menjamin kelangsungan hidup perusahaan dalam jangka panjang (Darma, 2006).

Tujuan dari kegiatan investasi adalah memperoleh berbagai manfaat atau keuntungan yang dinilai layak di masa yang akan datang. Manfaat utama yang diharapkan berupa pengembalian finansial dalam bentuk laba dari dana yang diinvestasikan. Manfaat lainnya adalah bersifat non finansial berupa penciptaan lapangan kerja, penggunaan bahan baku, peningkatan nilai ekspor, dan sebagainya. Jenis investasi sendiri dapat dibagi menjadi dua yaitu: investasi dalam bentuk financial assets dan investasi real asset (Halim, 2015; Darma, 2018; Darma, 2019). 


\section{Kebijakan Investasi (Penganggaran Modal)}

Pujiati dan Widanar dalam Pertiwi (2016) menjelaskan bahwa keputusan investasi menyangkut kegiatan mengeluarkan sejumlah dana saat ini sehingga diharapkan bisa mendapatkan arus kas dengan jumlah yang lebih besar daripada dana yang dikeluarkan pada saat sekarang. Keputusan terhadap jenis investasi seringkali dikaitkan dengan perencanaan strategis yang ingin dicapai dalam periode waktu tertentu yang dijabarkan dalam program tahunan perusahaan. Keputusan investasi diambil sebagai salah satu alternatif perusahaan untuk mengeluarkan dananya di luar kegiatan operasional yang bisa memberikan manfaat bagi perusahaan di masa mendatang.

Investasi modal dikatakan sebagai aspek utama dalam kebijakan manajemen keuangan karena investasi adalah bentuk alokasi modal yang realisasinya harus menghasilkan manfaat di masa yang akan datang (Harmono, 2017). Dijelaskan pula oleh Armen dan Azwar (2013) bahwa penganggaran modal memiliki beberapa tahapan yang dimulai dari adanya usulan rencana investasi dan diakhiri dengan evaluasi atas beberapa pilihan investasi. Setelah menetukan jenis investasi yang akan dilakukan, perusahaan juga harus berpikir tentang cara mendapatkan sumber dana yang akan mendanai investasi tersebut. Manajer keuangan harus membantu perusahaan menganalisa proyek-proyek yang menjanjikan dan memutuskan jumlah yang akan diinvestasikan dalam setiap proyek.

Keputusan pendanaan merupakan keputusan yang menyangkut struktur keuangan perusahaan (financial structure). Menurut Brigham dan Houston (2015) peningkatan aset perusahaan yang dilakukan melalui kebijakan investasi harus dibiayai oleh peningkatan modal. Ketika suatu perusahaan memerlukan dana, perusahaan bisa mengundang para investor untuk menanamkan sejumlah uang di mana nantinya akan ada pembagian laba di masa depan. Pilihan kedua adalah perusahaan menjanjikan untuk melunasi kas investor dengan tingkat bunga tertentu sesuai kesepakatan kedua belah pihak. Dalam hal ini para investor adalah pemberi pinjaman atau investor hutang yang suatu hari harus mendapatkan pelunasan. Adanya pilihan antara pendanaan ekuitas dan pendanaan hutang sering disebut dengan keputusan struktur modal.

\section{Evaluasi Kelayakan Investasi}

Dalam memutuskan jenis investasi, terutama bagi investasi yang nilainya cukup besar, pihak-pihak yang terlibat sebaiknya melakukan suatu studi kelayakan untuk menilai proyek tersebut dapat dikerjakan, ditunda, atau bahkan tidak dijalankan sama sekali. Dalam mengevaluasi suatu kelayakan investasi dari aspek keuangan terdapat beberapa metode yang 
digunakan oleh investor. Metode yang sering digunakan antara lain: NPV, IRR, dan Payback Period (Brealey, Myers, dan Marcus, 2008).

a. Nilai Sekarang (Net Present Value-NPV)

Nilai sekarang bersih dari suatu proyek mengukur selisih antara nilai pendapatan dan biayanya. NPV adalah jumlah nilai sekarang dari pendapatan dan pengeluaran selama umur proyek, setelah itu akan dihitung angka neto sehingga dapat diketahui selisihnya. Dalam menghitung nilai sekarang, investor mendiskontokan perkiraan hasil masa depan dengan tingkat pengembalian yang ditawarkan oleh alternatif investasi yang setara nilainya.

\section{NPV $=$ PV - investasi yang diperlukan}

Aturan NPV menyatakan bahwa manajemen berupaya meningkatkan kekayaan pemegang saham dengan menerima semua proyek yang bernilai positif di mana nilainya lebih besar daripada biayanya. Jika nilai sekarang bersih menunjukkan nilai negatif maka dapat dikatakan bahwa proyek tidak layak untuk dilanjutkan.

b. Tingkat Pengembalian Internal (Internal Rate of Return-IRR)

Ketika melakukan investasi terdapat suatu masa di mana terjadi keseimbangan antara semua pendapatan yang diperoleh dengan semua pengeluaran uang terjadi atas investasi tersebut. Tingkat bunga yang menyebabkan terjadinya posisi keseimbangan antara seluruh pendapatan dan pengeluaran pada periode waktu tertentu disebut dengan Internal Rate of Return. Dengan kata lain IRR merupakan tingkat diskonto yang memberikan proyek NPV dari suatu investasi sama dengan 0. Aturan IRR menyatakan bahwa jika IRR > tingkat pengembalian yang diinginkan maka proyek diterima, namun jika IRR < tingkat pengembalian yang diinginkan maka proyek ditolak dan tidak dilanjutkan.

c. Aturan Pembayaran Kembali Investasi (Payback Period-PP)

Pada dasarnya payback period merupakan jumlah periode (tahun) yang diperlukan untuk mengembalikan biaya investasi awal dengan tingkat pengembalian tertentu tanpa memperhatikan nilai waktu uang. Perhitungannya dilakukan berdasarkan aliran kas tahunan.

\section{PV Penerimaan - PV Pengeluaran $=0$}




\section{Penerapan Manajemen Risiko Dalam Kebijakan Investasi}

Keputusan investasi oleh perusahaan menimbulkan risiko strategis sebagai akibat dari ketidaktepatan dalam pengambilan suatu keputusan serta kegagalan dalam mengantisipasi perubahan lingkungan bisnis (Rustam, 2017). Ramli (2010) menjelaskan bahwa risiko investasi yang dihadapi oleh suatu perusahaan dipengaruhi oleh berbagai faktor baik dari internal maupun eksternal. Risiko internal misalnya berkaitan dengan aktivitas operasi, proses, atau pekerja. Faktor eksternal misalnya berkaitan dengan finansial, kebijakan pemerintah, tuntutan pasar, regulasi, dan lain-lain. Dalam hal ini direksi bertanggung jawab dalam penerapan manajemen risiko untuk berbagai risiko atas keputusan strategis. Menurut Rustam (2017) proses manajemen risiko terhadap suatu kebijakan investasi terdiri dari:

a. Identifikasi Risiko

Perusahaan harus mengidentifikasi serta mengelompokkan deviasi atau penyimpangan sebagai akibat tidak terealisasinya pelaksanaan strategi usaha maupun rencana bisnis yang telah ditetapkan, terutama yang berdampak signifikan terhadap permodalan perusahaan.

b. Pengukuran Risiko

Perusahaan melakukan pengukuran risiko dengan cara: mengidentifikasi perubahan lingkungan bisnis yang berdampak negatif terhadap asumsi awal dari rencana strategis dan mengukur dampak negatif suatu peristiwa terhadap kinerja bisnis perusahaan, baik secara keuangan maupun non keuangan. Apabila tingkat risiko lebih tinggi dibandingkan kemampuan perusahaan dalam menyerap risiko, maka akan dikembangkan suatu strategi untuk mengurangi atau memitigasi risiko tersebut.

c. Pemantauan Risiko

Perusahaan wajib memantau pengembangan implementasi strategi secara berkala. Pemantauan dilakukan dengan memperhatikan pengalaman kerugian di masa lalu. Isuisu strategis akibat perubahan operasional dan lingkungan bisnis yang berdampak negatif terhadap kondisi perusahaan wajib dilaporkan kepada jajaran direksi disertai dengan analisis dampak dan tindakan perbaikan yang diperlukan.

d. Pengendalian Risiko

Perusahaan harus memiliki sistem pengendalian dengan cara membandingkan hasil aktual dengan hasil yang diharapkan. Pengendalian risiko terhadap kinerja keuangan dapat dilakukan dengan menyusun cash flow budgeting yang nantinya akan dibandingkan dengan pencapaian perusahaan, di mana akan memunculkan suatu rencana strategi untuk memitigasi risiko. 


\section{Kerangka Konseptual}

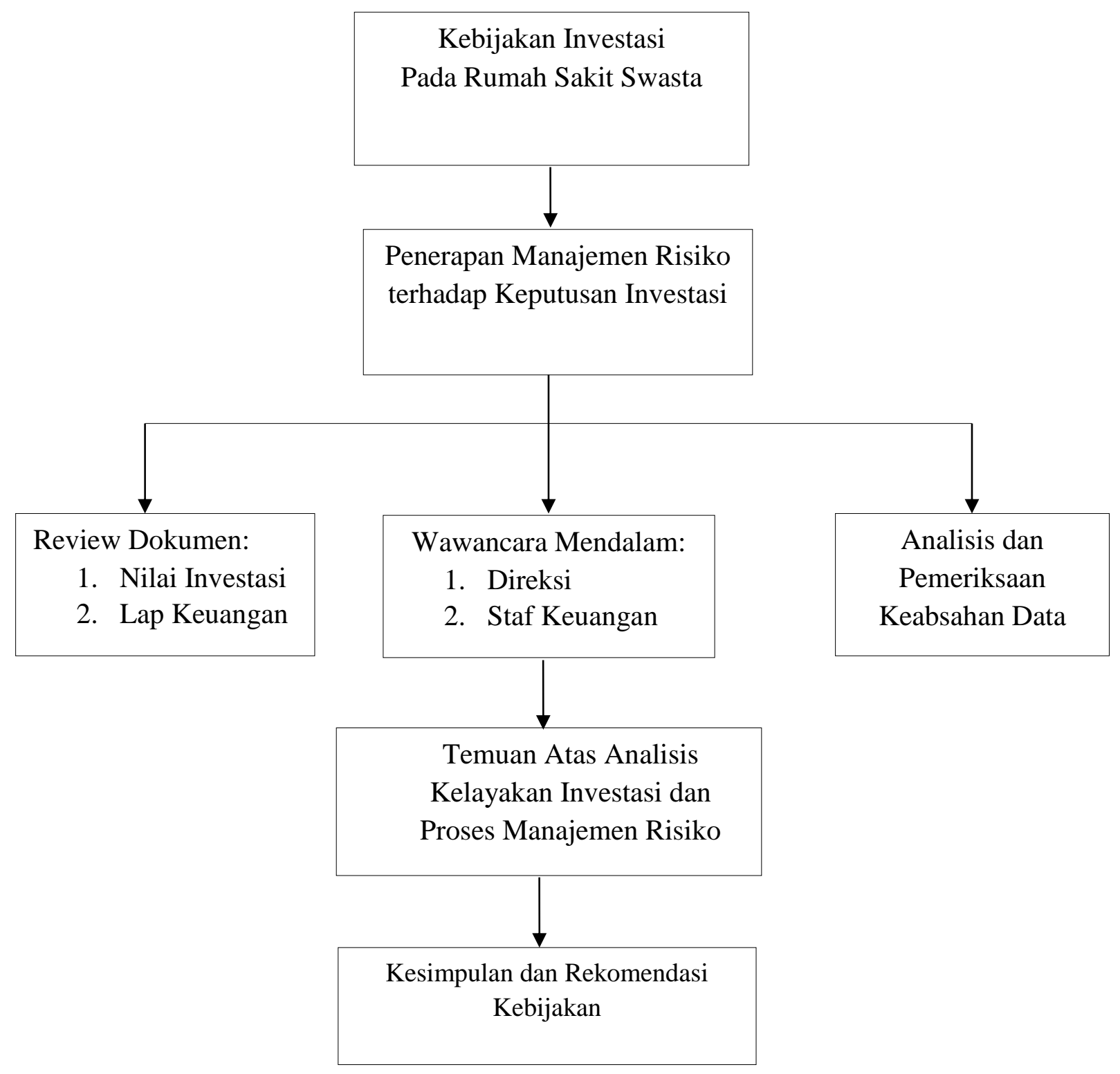

\section{METODE PENELITIAN}

Penelitian ini dilakukan di RSU Prima Medika Denpasar yang memutuskan kebijakan investasi dalam bentuk pengembangan fasilitas kesehatan. Metode yang digunakan dalam penelitian ini adalah pendekatan kualitatif dengan metode analisis deskriptif yang memberikan ruang bagi peneliti untuk memantau dan mengikuti proses dari implementasi kebijakan investasi dari aspek keuangan yang berbasis manajemen risiko.

Pengumpulan data menggunakan teknik dokumentasi dan wawancara mendalam (in depth interview) antara peneliti dengan informan untuk memperoleh penjelasan terkait fenomena masalah yang terjadi. Telaah dokumen menggunakan data-data laporan keuangan terkait operasional rumah sakit selama 3 tahun terakhir yaitu tahun 2015-2017, yang dipakai 
untuk menyusun cash flow budgeting sebagai dasar dalam menilai kelayakan investasi. Wawancara dilakukan dengan menyiapkan instrumen penelitian dalam bentuk pertanyaanpertanyaan tertulis. Pertanyaan penelitian disusun berdasarkan kajian teoritik serta telaah dokumen yang telah dipersiapkan sebelumnya.

Penentuan informan dalam penelitian ini menggunakan teknik purposive sampling yang didasarkan pada tujuan yang telah ditetapkan. Adapun informan yang dipilih untuk menjawab pertanyaan penelitian ini adalah jajaran direksi dan staf keuangan rumah sakit yang mengetahui implementasi kebijakan investasi rumah sakit. Data yang dikumpulkan selanjutnya akan dianalisis secara kualitatif dengan reduksi data, penyajian data, uji keabsahan data, dan penarikan kesimpulan.

\section{PEMBAHASAN}

\section{Kebijakan Investasi dan Keputusan Pendanaan}

Direksi RSU Prima Medika mengambil kebijakan investasi dalam bentuk pengembangan gedung rumah sakit dalam rangka memberikan pelayanan kesehatan kepada masyarakat. Kebijakan investasi dalam bentuk pengembangan rumah sakit mutlak diperlukan di tengah tuntutan kebutuhan masyarakat serta perubahan lingkungan yang dinamis. Salah satu pengembangan yang dilakukan adalah pembenahan fasilitas dan sarana prasarana sesuai standar Kementrian Kesehatan dan Akreditasi Rumah Sakit yang mengutamakan mutu pelayanan dan keselamatan pasien. Persyaratan akreditasi sangat penting dipenuhi sebagai salah satu syarat utama perpanjangan ijin operasional rumah sakit. Di samping itu rumah sakit dalam rangka persiapan menjadi salah satu provider BPJS Kesehatan sangat memerlukan daya dukung sarana prasarana. Investasi baru diperlukan dengan menambah kapasitas tempat tidur di IGD dan rawat inap, jumlah poliklinik, termasuk instalasi alkes di dalamnya serta menciptakan pelayanan terintegrasi.

Pengembangan rumah sakit sebagai layanan terpadu mengacu pada Renstra perusahaan dalam jangka waktu 5 tahun di mana dalam program tahunannya telah merencanakan suatu pembangunan fasilitas fisik/gedung baru. RSU Prima Medika telah melakukan analisa internal dan ekternal terhadap kebijakan investasi. Analisa internal menyangkut kekuatan dan kelemahan rumah sakit yang perlu dievaluasi. Manajemen optimis dengan kekuatan brand yang cukup kuat dan lokasi strategis di tengah Kota Denpasar akan mampu menggarap pasar yang lebih luas dan volume kunjungan pasien akan meningkat. Kelemahan rumah sakit terkait dengan penyediaan fasilitas pelayanan. Alternatif renovasi sulit dilakukan karena keterbatasan 
tempat serta dalam pelaksanaannya harus menutup operasional sehingga diperlukan pengembangan gedung beserta sarana penunjang lainnya.

Analisa eksternal terkait dengan keinginan rumah sakit untuk memanfaatkan peluang sebagai faskes lanjutan JKN karena adanya program pemerintah untuk mencapai universal coverage di tahun 2019. Hampir sebagian besar rumah sakit di Denpasar telah menjadi provider JKN agar mampu melayani pangsa pasar yang lebih luas, dengan tetap mengedepankan mutu pelayanan dan keselamatan pasien. Hal ini tentu saja menjadi tantangan bagi seluruh rumah sakit saat ini untuk bersaing ketat dalam memberikan pelayanan kesehatan terbaik dengan menawarkan seluruh sumber daya yang mereka miliki. Fasilitas dan prasarana rumah sakit yang memadai tentu akan mendukung tercapainya pelayanan paripurna.

Mengingat perjalanan usaha yang cukup panjang dan gambaran ke depan menunjukkan optimisme bahwa kesehatan sebagai kebutuhan dasar masyarakat yang harus terpenuhi serta keinginan kuat para pemilik agar rumah sakit tetap maju maka pengembangan fasilitas untuk mengantisipasi kondisi tersebut sangat diperlukan. Adanya kebutuhan dan keinginan rumah sakit untuk memenuhi harapan masyarakat terhadap pelayanan kesehatan yang memuaskan menyebabkan perusahaan perlu mengembangkan investasi terutama dalam upaya menghadapi tantangan persaingan yang semakin ketat.

RSU Prima Medika memutuskan penggunaan dana internal dan eksternal untuk membiayai investasi. Awalnya dana internal dioptimalkan penggunaannya seperti: simpanan perusahaan dalam bentuk giro maupun deposito, serta mengajak para pemilik dan para dokter spesialis untuk menambah modal perusahaan melalui penjualan saham. Dana internal yang diperoleh ternyata belum cukup untuk menutupi biaya investasi, sehingga perusahaan memutuskan menambah hutang bank dengan jumlah tertentu. Skema kredit bank diatur sedemikian rupa berdasarkan jangka waktu dan suku bunga tertentu sehingga diperoleh nilai angsuran sesuai kemampuan perusahaan.

Rencana Anggaran Biaya atas proyek pengembangan rumah sakit telah disusun sesuai kebutuhan, seperti: pengeluaran gedung, instalasi, alat-alat kesehatan, dan alat-alat non medis. Namun dalam perjalanan proyek terdapat penambahan nilai investasi atas persetujuan pemilik dan direksi berupa pengembangan alat kesehatan, ruang perawatan, ruang steril sentral, bank darah yang dianggap perlu untuk dikembangkan. Perusahaan dengan banyak pemilik tentu menimbulkan berbagai kepentingan. Di awal pemilik tidak banyak melakukan koreksi terhadap perencanaan, namun selama proyek berjalan muncul perubahan yang tentunya menambah pengeluaran. Dengan demikian telah terjadi penyimpangan antara RAB dan realisasi. 
Selain itu muncul pula pengeluaran-pengeluaran di luar proyek yang sifatnya urgent dengan nominal cukup besar. Nilai yang material ini sangat mempengaruhi pendanaan proyek karena pengeluaran tersebut belum dicadangkan sebelumnya. Rencana Anggaran Biaya yang disusun sebelumnya hanya disesuaikan dengan kebutuhan proyek saja dan tidak dicadangkan untuk pengeluaran lain-lain. Hal ini tentu saja berdampak pada terganggunya cash flow, bahkan menimbulkan defisit saat nilai pengeluaran proyek melebihi penerimaan. Sampai saat ini RSU Prima Medika masih berupaya untuk menutupi hutang jangka pendek kepada beberapa vendor proyek akibat masalah cash flow.

\section{Analisa Kelayakan Investasi dari Aspek Keuangan}

Kebijakan investasi RSU Prima Medika dalam bentuk pengembangan fasilitas dan prasarana telah melalui analisa kelayakan investasi dari aspek keuangan. Rumah sakit menggunakan Kantor Jasa Penilai Publik untuk mambantu membuatkan analisa bisnis terhadap investasi pengembangan rumah sakit, terutama terkait keuangan. Data-data keuangan 3 tahun terakhir diberikan sebagai acuan dalam menyusun cash flow budgeting rumah sakit akibat adanya penambahan investasi ini. Hasil penilaian konsultan menunjukkan bahwa investasi layak dan dapat dilanjutkan. Walaupun analisa tidak spesifik dilakukan terhadap operasional dan bisnis gedung baru, namun analisa KJPP ini telah digunakan untuk proses pengajuan kredit di bank.

Dalam hal ini peneliti menganalisa kembali kelayakan investasi dari aspek keuangan yang telah dilakukan sebelumnya. Data keuangan yang diambil adalah laporan laba rugi perusahaan 3 tahun terakhir yaitu tahun 2015-2017. Peneliti membuat analisa finansial berupa proyeksi pendapatan dan biaya operasional selama 15 tahun. Berdasarkan hasil proyeksi laba rugi, peneliti melakukan perhitungan kelayakan atas investasi dalam bentuk pengembangan gedung dan sarana prasarana dengan menggunakan tiga metode yaitu:

a. Nilai Sekarang (Net Present Value-NPV)

Net Present Value merupakan selisih nilai antara serangkaian penerimaan di masa akan datang (setelah dinilai saat ini dengan tingkat diskonto tertentu), dengan investasi yang dilakukan pada saat ini. Investasi dikatakan layak apabila selisih penerimaan dan pengeluaran tersebut menunjukkan nilai positif, begitu pula sebaliknya. Hasil NPV dalam analisa kelayakan ini adalah positif dengan nilai sebesar Rp. 463.592 .397 maka dapat dikatakan bahwa kebijakan investasi RSU Prima Medika dalam bentuk pengembangan gedung layak dilakukan. 


\section{b. Tingkat Pengembalian Internal (Internal Rate of Return-IRR)}

Internal Rate Return merupakan tingkat diskonto yang memberi proyek NPV dari suatu investasi sama dengan 0. Aturan IRR menyatakan bahwa jika IRR > tingkat pengembalian yang diinginkan maka proyek diterima, begitu pula sebaliknya. Perhitungan IRR untuk proyeksi 15 tahun operasional dalam analisa kelayakan ini adalah sebesar 10,62\%. Berarti nilainya lebih tinggi dibandingkan tingkat pengembalian yang diharapkan, sehingga kebijakan investasi yang telah dilakukan dianggap layak.

c. Aturan Pembayaran Kembali Investasi (Payback Period-PP)

Berbeda halnya dengan metode NPV dan IRR yang mencerminkan nilai waktu uang, perusahaan sering menggunakan aturan praktis untuk menilai proyek. Salah satunya adalah dengan metode Payback Period atau aturan pembayaran kembali investasi. Payback Period merupakan jumlah periode (tahun) yang diperlukan untuk mengembalikan seluruh biaya investasi yang sudah ditanamkan. Dalam analisa kelayakan ini, PP atas investasi gedung baru RSU Prima Medika dicapai dalam waktu 8 tahun.

\section{Manajemen Risiko dalam Kebijakan Investasi}

Berdasarkan informasi yang diperoleh dari proses wawancara dengan jajaran direksi diketahui bahwa penerapan manajemen risiko dalam kebijakan investasi RSU Prima Medika belum berjalan optimal. Adapun penerapan manajemen risiko terhadap kebijakan investasi RSU Prima Medika dapat dijelaskan sebagai berikut:

a. Identifikasi risiko

RSU Prima Medika telah mengidentifikasi adanya risiko-risiko yang akan muncul dari adanya kebijakan investasi. Rumah sakit merupakan salah satu institusi yang rentan terhadap risiko regulasi. Dalam pelaksanaan kegiatan operasionalnya, rumah sakit sangat dipengaruhi oleh regulasi pemerintah yang senantiasa berubah dan wajib diikuti. Salah satunya adalah terkait pelayanan pasien BPJS Kesehatan. Pada tahun 2015 rumah sakit belum diwajibkan menjadi provider BPJS Kesehatan, namun di tengah perjalanan regulasi berubah di mana rumah sakit harus melayani pasien BPJS untuk mendukung program universal coverage.

Pada tahun 2018 RSU Prima Medika kembali dihadapkan oleh perubahan peraturan BPJS Kesehatan yang menerapkan sistem rujukan berjenjang. Regulasi ini berdampak terhadap penurunan volume pasien di rumah sakit tipe A dan tipe B karena pasien akan tersaring di rumah sakit tipe C dan tipe D. Namun RSU Prima Medika 
terlanjur membangun konsep rumah sakit tipe B dengan berbagai fasilitas pendukung, seperti: layanan bank darah, cath lab, ICU 9 bed, IGD 9 bed, yang tentu saja berbiaya investasi tinggi.

Risiko lainnya yang akan dihadapi terkait kebijakan investasi dalam bentuk pengembangan rumah sakit adalah risiko finansial. Hasil cash flow budgeting yang telah disusun sebelumnya sangat rentan dengan ketidakpastian. Penambahan biaya investasi yang tidak diperhitungkan dalam Rencana Anggaran Biaya serta keuntungan yang tidak mencapai target tentu saja akan berdampak pada semakin panjangnya jangka waktu pengembalian investasi. Pendanaan investasi dengan menggunakan dana pihak ketiga akan memunculkan kewajiban untuk membayar setiap bulannya. Selain itu kebijakan investasi baru tentu saja akan menambah nilai fixed cost, seperti: beban gaji, utility, beban pemeliharaan, pemakaian bahan habis pakai, termasuk beban bunga bank harus dialokasikan.

Tantangan lain terkait risiko keuangan muncul saat RSU Prima Medika telah bekerja sama dengan BPJS Kesehatan, di mana tarif BPJS jauh di bawah publish rate dan sistem pembayarannya bersifat tidak langsung sehingga menimbulkan piutang hingga mencapai 2-3 bulan. Dengan demikian RSU Prima Medika harus menjaga cash flow agar tidak mengganggu likuiditas perusahaan, mampu mengelola pendapatan, serta menutupi seluruh biaya-biaya yang muncul akibat aktivitas operasional.

b. Pengukuran Risiko

RSU Prima Medika tidak melakukan pengukuran risiko dari adanya kebijakan investasi. Setelah risiko investasi ditentukan seharusnya dijabarkan frekuensi dan dampak sehingga diketahui nilai risiko. Hal ini penting dilakukan untuk mengetahui prioritas mitigasi risiko berdasarkan nilai risiko, di mana umumnya mitigasi risiko akan berfokus pada risiko yang bernilai besar (artinya frekuensi sering terjadi dan dampaknya besar bagi kinerja bisnis perusahaan). Biaya mitigasi risiko sebaiknya dimasukkan dalam penambahan RAB sebagai pencadangan biaya untuk mengantisipasi risiko-risiko yang mungkin terjadi, misalnya modal tidak mencukupi, keterlambatan proyek, kenaikan harga bahan, rendahnya kunjungan, dan sebagainya.

c. Pemantauan Risiko

Pemantauan risiko dilakukan dengan memperhatikan pengalaman kerugian di masa lalu yang disebabkan oleh kebijakan investasi atau penyimpangan pelaksanaan rencana strategis. Direktur RSU Prima Medika selaku pejabat yang bertanggung jawab dalam pengelolaan operasional selalu memantau setiap perubahan yang terjadi serta 
memperbaharui informasi terkait regulasi pemerintah dari berbagai media, asosiasi rumah sakit, serta Badan Penyelenggara Jasa Kesehatan. Informasi tersebut tidak hanya penting dalam pengelolaan operasional melainkan juga untuk pembuatan keputusan strategis perusahaan. Isu-isu strategis yang timbul akibat perubahan operasional dan lingkugan bisnis yang memiliki dampak terhadap kondisi perusahaan disampaikan oleh direktur rumah sakit kepada direktur perusahaan sebagai dasar dalam analisis dampak serta tindakan perbaikan yang diperlukan.

d. Pengendalian Risiko

Tahap awal dalam proses pengendalian risiko atas kebijakan investasi rumah sakit adalah dengan menyusun cash flow budgeting agar bisa membandingkan hasil aktual dengan hasil yang diperkirakan serta mengetahui penyimpangan yang terjadi. Cash flow budgeting ini dapat dijadikan acuan dalam menilai pencapaian target perusahan agar selanjutnya bisa disusun strategi untuk memitigasi risiko. Adapun strategi utama yang akan dilakukan RSU Prima Medika untuk mengendalikan risiko investasi adalah memaksimalkan utility gedung dan seluruh fasilitas dalam upaya memberikan pelayanan kesehatan kepada masyarakat. Rumah sakit saat ini menunda proses naik kelas ke Tipe B dengan alasan mengisi kapasitas dari semua fasilitas pelayanan dan memaksimalkan volume kunjungan. Dengan cara tersebut diharapkan rumah sakit mampu mencapai tingkat keuntungan yang diharapkan.

Fokus RSU Prima Medika saat ini adalah meningkatkan sales dan mengurangi cost untuk memaksimalkan keuntungan. Pendapatan rumah sakit harus ditingkatkan melalui pelayanan seluruh tipe pasien dengan harga yang competitive, memanfaatkan seluruh fasilitas pelayanan sehingga menjadi daya tarik pasien untuk berobat, menjalankan strategi pemasaran dengan menambah jumlah kerjasama, memberikan promo harga khusus, hingga mengembangkan digital marketing untuk jangkauan pasar yang lebih luas. Sedangkan kendali biaya dilakukan dengan efisiensi pemakaian operasional hingga substitusi vendor.

\section{PENUTUP}

Berdasarkan hasil penelitian dapat disimpulkan bahwa kebijakan investasi dalam bentuk pengembangan rumah sakit mutlak diperlukan di tengah tuntutan kebutuhan masyarakat serta perubahan lingkungan yang dinamis. Telah dilakukan perhitungan biaya investasi serta penentuan sumber dana untuk membiayai investasi tersebut, di mana pendanaan investasi berasal dari pihak internal dan eksternal. Namun dalam proses pelaksanaannya, 
manajemen mengalami masalah over budget investasi yang disebabkan oleh adanya beberapa rekomendasi shareholder di luar kesepakatan. Selain itu muncul pengeluaran-pengeluaran di luar proyek yang sifatnya urgent dengan nominal cukup besar. Hal ini tentu saja berdampak pada terganggunya cash flow perusahaan.

Hasil dari perhitungan menggunakan metode NPV (Net Present Value) diperoleh nilai positif sebesar Rp. 463.592.397. Dengan metode IRR (Internal Rate of Return) diperoleh tingkat bunga sebesar 10,62\% dan metode PP (Payback Period) menunjukkan pengembalian biaya investasi dicapai dalam jangka waktu 8 tahun. Berdasarkan hasil analisa dengan 3 metode tersebut dapat disimpulkan bahwa investasi RSU Prima Medika dalam bentuk pengembangan gedung layak dilakukan.

Terkait dengan adanya risiko atas investasi yang dilakukan, RSU Prima Medika belum menerapkan proses manajemen risiko secara optimal. Proses manajemen risiko yang dilakukan hanya sebatas identifikasi, pemantauan, dan pengendalian risiko. Pengukuran risiko tidak dilakukan di mana nilai investasi tidak memperhitungkan atau mencadangkan kemungkinan tambahan pengeluaran sebagai akibat dari adaya risiko investasi. Kurang optimalnya pengelolaan manajemen risiko terhadap kebijakan investasi rumah sakit dapat berpotensi menimbulkan risiko kerugian finansial maupun nonfinansial.

Dalam penelitian ini telah diperoleh hasil kajian investasi rumah sakit layak dan dapat dilanjutkan. Perhitungan cash flow budgeting selama periode 15 tahun dapat digunakan sebagai acuan bagi manajemen RSU Prima Medika dalam penentuan target pendapatan dan biaya. Perlu adanya komitmen manajemen dalam rangka optimalisasi pendapatan serta efisiensi biaya terkait operasional rumah sakit.

Selain itu manfaat penelitian ini adalah sebagai bahan pertimbangan dan evaluasi dalam menerapkan manajemen risiko terhadap kebijakan investasi rumah sakit. Proses manajemen risiko tetap dijalankan walaupun hasil kajian terhadap investasi pengembangan rumah sakit menunjukkan layak dan dapat dilanjutkan. Risk management diperlukan untuk memastikan bahwa asumsi-asumsi berjalan sesuai dengan perencanaan sebelumnya, terutama terkait pengembangan berbagai strategi mitigasi risiko. Manfaat investasi diliputi oleh ketidakpastian yang mengandung berbagai risiko sehingga manajemen perlu menyusun kebijakan untuk mitigasi risiko dalam bentuk:

a. Memperkuat fungsi marketing perusahaan;

b. Menyusun strategi marketing bagi pasien rumah sakit peserta BPJS Kesehatan;

c. Membuat layanan unggulan dengan memanfaatkan fasilitas rumah sakit untuk menyasar pasien reguler dan kerjasama, terutama pasien menengah ke atas; 
d. Meningkatkan kualitas pelayanan kesehatan sehingga mampu mempertahankan customer serta menjaring pangsa pasar yang lebih luas;

e. Menerapkan lean management dengan konsep hemat, adaptif, dan inovatif untuk meningkatkan sales dan menurunkan cost rumah sakit.

Penelitian ini memiliki keterbatasan di mana hanya terfokus pada aspek keuangan dalam analisa kelayakan investasi pengembangan gedung dan sarana prasarana rumah sakit, sedangkan analisa kebijakan investasi dapat dinilai dari beberapa aspek, seperti: aspek teknis, aspek ekonomi dan sosial, aspek pasar dan pemasaran, hingga aspek hukum. Diharapkan penelitian selanjutnya dapat melengkapi kekurangan dan keterbatasan penelitian ini dengan menambahkan aspek lain sebagai acuan dalam menganalisa kelayakan investasi. 


\section{DAFTAR PUSTAKA}

Andampury, F.S., Dewi, A., \& Marwati, T. (2016). Analisis Kebijakan Investasi Alat Radiologi C-Arm Rumah Sakit X, Jurnal Fakultas Kesehatan Masyarakat, 10 (1): 43-54.

Armen, F \& Azwar, V. (2013). Dasar-Dasar Manajemen Keuangan Rumah Sakit. Yogyakarta: Gosyen Publishing.

Bastian, I. (2015). Akuntansi Kesehatan. Yogyakarta: BPFE.

Brigham, E. F., J.F. Houston. (2015). Fundamentals of Financial Management. USA: Cengage Learning.

Brealey, R. A., S.C. Myers, \& Marcus, A.J. (2008). Dasar-Dasar Manajemen Keuangan Perusahaan, 5th ed. Jakarta: Erlangga.

Darma, G.S. (2019). Kacamata Media, Kesuksesan Bersyarat. Indonesia: Pustaka Larasan Press.

Darma, G.S. (2018). Seuntai Pesan, Menjawab Zaman. Indonesia: Pustaka Larasan Press.

Darma, G.S. (2006). Mobile Marketing: Sebuah Strategi Keunggulan Bersaing Online. Denpasar: Undiknas Press.

Depkes RI. (2009). Undang-Undang Nomor 44 Tahun 2009 tentang Rumah Sakit. Jakarta: Departemen Kesehatan RI.

Halim, A. (2015). Analisis Investasi di Aset Keuangan, 1st ed. Jakarta: Mitra Wacana Media. Harmono. (2017). Manajemen Keuangan Berbasis Balanced Scorecard Pendekatan Teori, Kasus, dan Riset Bisnis. Jakarta: Bumi Aksara.

Hendhana, S., \& Darma, G.S. (2017). Service Quality Rumah Sakit dan Efeknya terhadap Patient Satisfaction, Perceived Value, Trust, dan Behavioral Intention, Jurnal Manajemen \& Bisnis, 14 (1): 37-55.

Jogiyanto. (2010). Teori Portofolio dan Analisis Investasi. Yogyakarta: BPFE.

Khariza, H.A. (2015). Studi Deskriptif Tentang Faktor-Faktor yang Dapat Mempengaruhi Keberhasilan Implementasi Program Jaminan Kesehatan Nasional di Rumah Sakit Jiwa Menur Surabaya, Jurnal Kebijakan dan Manajemen Publik, 3 (1): 1-7.

Pertiwi, P.J., Tommy, P., \& Tumiwa, J.R. (2016). Pengaruh Kebijakan Hutang, Keputusan Investasi, dan Profitabilitas Terhadap Nilai Perusahaan Food and Beverage yang Terdaftar di Bursa Efek Indonesia, Jurnal EMBA, 4 (1): 1369-1380.

Pidada, I.A.D.U., and Darma, G.S. (2018). Kerja Sama Tim Perawat Dalam Meningkatkan Keselamatan Pasien Berbasis Tri Hita Karana, Jurnal Manajemen \& Bisnis, 15 (2): 137-148. 
Ramli, S. (2010). Pedoman Praktis Manajemen Risiko Dalam Perspektif K3. Jakarta: Dian Rakyat.

Rustam, B.R. (2017). Manajemen Risiko: Prinsip, Penerapan, dan Penelitian. Jakarta: Salemba Empat.

Setyawati, T., and Darma, G.S. (2018). Efektifkah Experiential Marketing di Sebuah Rumah Sakit ?, Jurnal Manajemen \& Bisnis, 15 (1): 160-175.

Sucita, I.K., \& Broto, A.B. (2010). Analisis Investasi Proyek Rumah Sakit Internasional MH. Thamrin Bogor, Jurnal Poli Teknologi, 9 (1): 30-42.

Yulianingtyas, R., Wigati, P.A., \& Suparwati, A. (2016). Analisis Pelaksanaan Manajemen Risiko di Rumah Sakit Islam Sultan Agung Semarang, Jurnal Kesehatan Masyarakat, 4 (4): 121-128. 